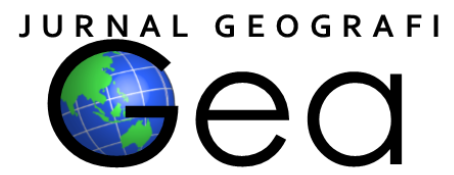

\title{
ZONASI KARAKTERISTIK PENCEMARAN UNTUK PENYUSUNAN STRATEGI DAN POLA AKSI PENANGANAN SUNGAI MENUJU CITARUM HARUM (PEMETAAN DENGAN CITRA TEGAK RESOLUSI TINGGI)
}

\author{
Dede Rohmat $^{1}$, Iwan Setiawan ${ }^{2}$, Asri R Affriani ${ }^{3}$ \\ ${ }^{1,2,3}$ Departemen Pendidikan Geografi, Fakultas Pendidikan Ilmu Pengetahuan Sosial, \\ Universitas Pendidikan Indonesia \\ ${ }^{1}$ dederohmat@upi.edu
}

\begin{abstract}
Pollution in the Citarum river basin has an impact on the degradation of river functions. The surrounding community and the government need a special strategy to maintain the suitability and sustainability of river functions. This study aims: (1) to find out the drainage and waste disposal systems pattern in the Citarum river; (2) knowing the mindset and behavior of the community about the importance of maintaining the role of the Citarum River for future; and (3) determine the strategy for handling Citarum river pollution. Spatial approach, survey and FGD (Forum Group Discussion) are used to study the characteristics of pollution as a compiler of strategies and patterns of action for handling rivers towards fragrant Citarum. The results showed that most of the waste discharged directly into the river through the drainage channels without prior processing. Most are not well connected to each other. The priority problems in the study area are the absence of: (1) particular institutions to handle the environmental issues; (2) well-connected drainage system; (3) good and complete handling and treatment of waste and garbage; (4) the synergy between environment-based programs at the village; (5) partnership-based activities at the level of the smallest administrative unit/village; (6) financial support and environmental engineering capabilities. Therefore, the plan of partnership-based activities among community and stakeholders is needed, which is oriented to the formation of a strong partnership and synergy to build and develop a Citarum River pollution handling model.
\end{abstract}

Keywords: Citarum, Strategy, Pattern of Action, River Pollution

\begin{abstract}
ABSTRAK
Pencemaran pada area Sungai Citarum memberikan dampak terhadap degradasi fungsi sungai. Masyarakat sekitar dan pemerintah memerlukan strategi khusus demi terjaganya kesesuaian dan keberlanjutan fungsi sungai. Penelitian ini bertujuan: (1) mengetahui pola sistem drainase dan pembuangan limbah di sungai Citarum; (2) mengetahui pola pikir dan perilaku masyarakat tentang pentingnya menjaga peran Sungai Citarum untuk keberlangsungan kehidupan mendatang; dan (3) menentukan strategi penanganan pencemaran sungai Citarum. Pendekatan spasial, survei serta FGD (Forum Group Discussion) digunakan untuk mengkaji karakteristik pencemaran sebagai penyusun strategi serta pola aksi penanganan sungai menuju Citarum harum. Hasil penelitian menunjukkan bahwa sebagai besar limbah dibuang langsung ke sungai melalui saluransaluran drainase tanpa pengolahan terlebih dahulu. Sebagian besar belum terkoneksi dengan baik. Secara rill permasalahan prioritas di daerah kajian adalah tidak adanya: (1) lembaga/kelembagaan khusus untuk menangani masalah lingkungan; (2) sistem drainase
\end{abstract}


yang terkoneksi dengan baik; (3) penanganan dan pengolahan limbah dan sampah yang baik dan tuntas; (4) sinerginisitas antar program berbasis lingkungan di tingkat desa; (5) kegiatan berbasis kemitraan pada tingkat satuan adminitratif terkecil/desa; (6) dukungan dana dan kemampuan rekayasa lingkungan. Oleh karena itu diperlukan perancangan kegiatan berbasis kemitraan antar stake holder atas nama masyarakat, yang berorientasi pada terbentuknya kemitraan yang kokoh dan mampu bekerja sinergi untuk membangun dan mengembangkan row model penanganan pencemaran Sungai Citarum.

Kata kunci: Citarum, Strategi, Pola Aksi, Pencemaran sungai

\section{PENDAHULUAN}

Sungai Citarum menjadi urat nadi bagi kehidupan masyarakat sepanjang dan sekitan daerah alirannya. Kondisi sungai Citarum saat ini sudah semakin mengkhawatirkan. Masalah yang ada pada sungai Citarum saat ini adalah banjir, banyaknya sampah, tebalnya sedimen, dan banyaknya limbah dibuang ke sungai Citarum. Aktivitas di sekitaran sungai seperti industri akan berpengaruh terhadap kualitas air sungai, karena mengakibatkan konsentrasi limbah yang melebihi daya asimilasi (kemampuan menetralisasi) badan air yang terkontaminasi (Dawud et al, 2016). Masyarakat sekitar akan terkena dampak dari pencemaran sungai Citarum, baik secara langsung maupun tidak langsung. Sungai memberikan berbagai fungsi dan layanan ekosistem yang menopang keanekaragaman hayati dan kesejahteraan manusia (Singh et al, 2019).

Sungai Citarum termasuk dalam wilayah sungai Strategis nasional. Upaya pemerintah untuk pengendalian sungai antara lain dengan mengeluarkan Keputusan Presiden RI Nomor 12 Tahun 2012, yang menyatakan bahwa sungai merupakan Kawasan Strategis Nasional. Gubernur Jawa Barat mengeluarkan program Citarum Harum. Program tersebut berfokus pada perbaikan kondisi sungai Citarum. Perbaikan tersebut meliputi pengendalian kerusakan, pencemaran dan pemulihan DAS Citarum. Pencemaran sungai merupakan masalah serius bagi kualitas air, merusak ekologi dan mengancam mata pencaharian masyarakat, terutama di area perkotaan yang berdekatan dengan industri (Whitehead et al, 2019). Peran pemerintah dan masyarakat perlu dibangkitkan untuk pengelolaan sungai Citarum.

Pengelolaan DAS harus didasarkan kepada pemahaman risiko dan permasalahan utama yang terjadi, sehingga penanganan akan berjalan efektif dan effisien (Tsaboula et al, 2019). Terdapat beberapa penelitian di DAS Citarum yaitu Distribusi Spasial Tingkat Pencemaran Air di Das Citarum (Cahyaningsih dan Harsoyo, 2010), Rencana Tindak Pengelolaan DAS Citarum(Mulyana Arif Jaya \& Risdiyanto, 2013), Pemodelan Banjir dan Analisis Kerugian Akibat Bencana Banjir di DAS Citarum Hulu (Muin, Muin, Boer, \& Suharnoto, 2015) dan Pelatihan Pemeliharaan Keletarian Kelestarian Mata Air Melalui Implementasi Metoda Imbuhan Buatan Sederhana di Kawasan DAS Bagian Bagian Hulu (Studi Kasus DAS Citarum Bgian Hulu Mata Air Cisanti) (Rohmat, Setiawan, Soemantri, 2015).

Upaya pengendalian sungai Citarum sebelumnya sudah dilakukan oleh banyak sektor, namun bersifat parsial, sektoral dan tidak berlanjut. Kondisi ini menjadikan program pengendalian tersebut tidak berjalan dengan sukses, karena tidak dapat bersinergi antar program dari antar sektor. Oleh sebab itu, program Citarum Harum yang saat ini digalakkan merangkul berbagai sektor kementrian termasuk sektor pendidikan agar dapat diperoleh suatu konsep strategis bagaimana mengintegrasikan berbagai kegiatan tersebut agar sinergi dan berkelanjutan. Manajemen pengelolaan sungai harus melibatkan berbagai sektor kepentingan yang berhubungan dengan permasalahan terkait (Angriani et al, 2019). Aspek sosial kelembagaan merupakan aspek penting prioritas yang perlu dikembangkan dalam pengendalian pencemaran sungai (Agustiningsih, 2012).

Penelitian ini bertujuan: (1) mengetahui pola sistem drainase dan pembuangan limbah di sungai Citarum; (2) mengetahui pola pikir dan perilaku masyarakat tentang pentingnya menjaga peran Sungai Citarum untuk keberlangsungan kehidupan mendatang; dan 
(3) menentukan strategi penanganan pencemaran sungai Citarum. Pendekatan spasial dan survei digunakan untuk mengkaji karakteristik pencemaran sebagai penyusun strategi serta pola aksi penanganan sungai menuju Citarum harum. Penelitian ini dapat menjadi sumbangsih bagi institusi terkait dan masyarakat yang menangani permasalahan di area sungai Citarum.

\section{STUDY AREA}

Sungai Citarum memiliki panjang kurang lebih $300 \mathrm{~km}$ degan hulu di Gunung Wayang dan hilir di Kabupaten Karawang.
Indeks kerapatan DAS Citarum yaitu 0,28 $\mathrm{km} / \mathrm{km}^{2}$, masuk kepada indeks kerapatan sungai sedang. DAS yang membulat memberi pengaruh yang signifikan terhadap waktu konsentrasi run off untuk terkonsentrasi di badan Sungai Citarum. Kajian penelitian meliputi daerah DAS Citarum yang berada di 2 kecamatan meliputi 3 Desa yaitu Desa Pameuntasan, Desa Cilampeni dan Desa Dayeuhkolot, Kabupaten Bandung, Jawa Barat. Daerah penelitian berada pada bagian Cekungan Bandung dengan elevasi rata-rata 662 mdpl.

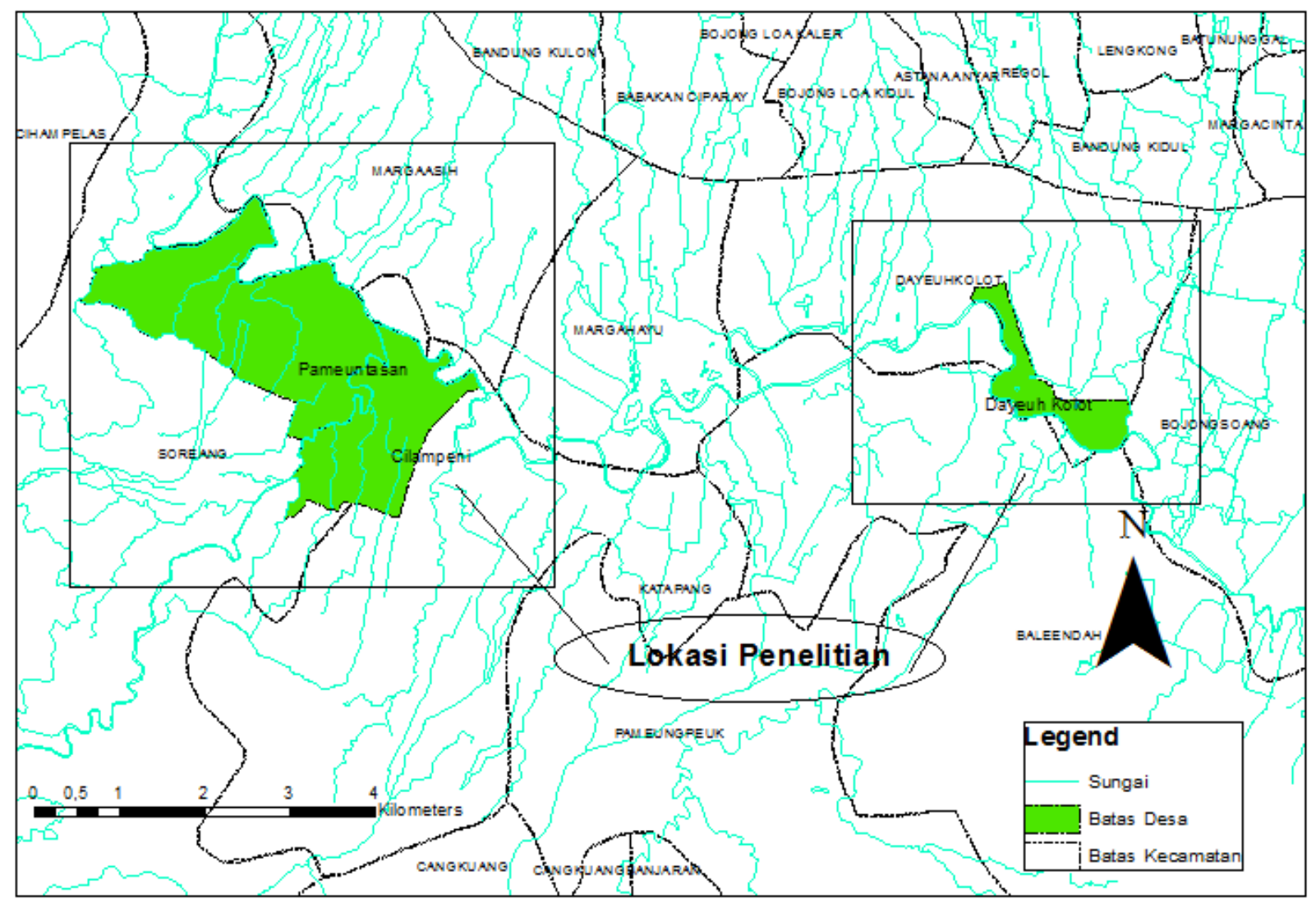

Gambar 1. Peta Lokasi Studi

\section{METODE PENELITIAN}

Penelitian ini dilakukan secara bertahap dengan penyesuaian kondisi eksisting sekitar yang dilakukan selama 3 tahun, mulai tahun 2018 hingga tahun 2020. Identifikasi spasial, survei serta FGD (Forum Group Discussion) dipakai untuk mengetahui lingkup kajian. Berikut lingkup kajian yang dianalisis:

1. Inventarisasi dan identifkasi kondisi hidrologis DAS Citarum.

2. Deliniasi batas DAS Citarum.

3. Kajian penyebab pencemaran air, Identifikasi Sub-DAS Kritis yang terdapat di DAS Citarum, Mengkaji CAT (Cekungan Air Tanah).

4. Mengkaji tingkat kualitas air.

5. Mengkaji perilaku masyarakat DAS Citarum serta pengaruhnya terhadap kondisi DAS Citarum.

6. Menentukan daerah skala prioritas untuk penanganan pencemaran air di DAS Citarum.

7. Rumusan pengendalian DAS Citarum yang sudah dilakukan

8. Rumusan strategi dan pola aksi "Pengendalian DAS Citarum". 
9. Daerah, objek, dan skala proritas pengendalian DAS Citarum.

10. Pilot Project strategi dan rencana aksi pengendalian DAS Citarum.

Pengetahuan ruang lingkup kajian berfungsi untuk merinci tujuan penelitian yaitu: (1) mengetahui pola sistem drainase dan pembuangan limbah di sungai Citarum; (2) mengetahui pola pikir dan perilaku masyarakat tentang pentingnya menjaga peran Sungai Citarum untuk keberlangsungan kehidupan mendatang; dan (3) menentukan strategi penanganan pencemaran sungai Citarum. Tehnik sampling yang dipakai yaitu purposive sampling dengan jumlah 75 responden dengan kondisi desa. Instrumen penelitian mengacu kepada kondisi sosial ekonomi, kondisi rumah, kondisi bangunan rumah, luas rumah, sumber air, kondisi sanitas dan sampah, dampak banjir, dan strategi penanganan pencemaran Citarum.

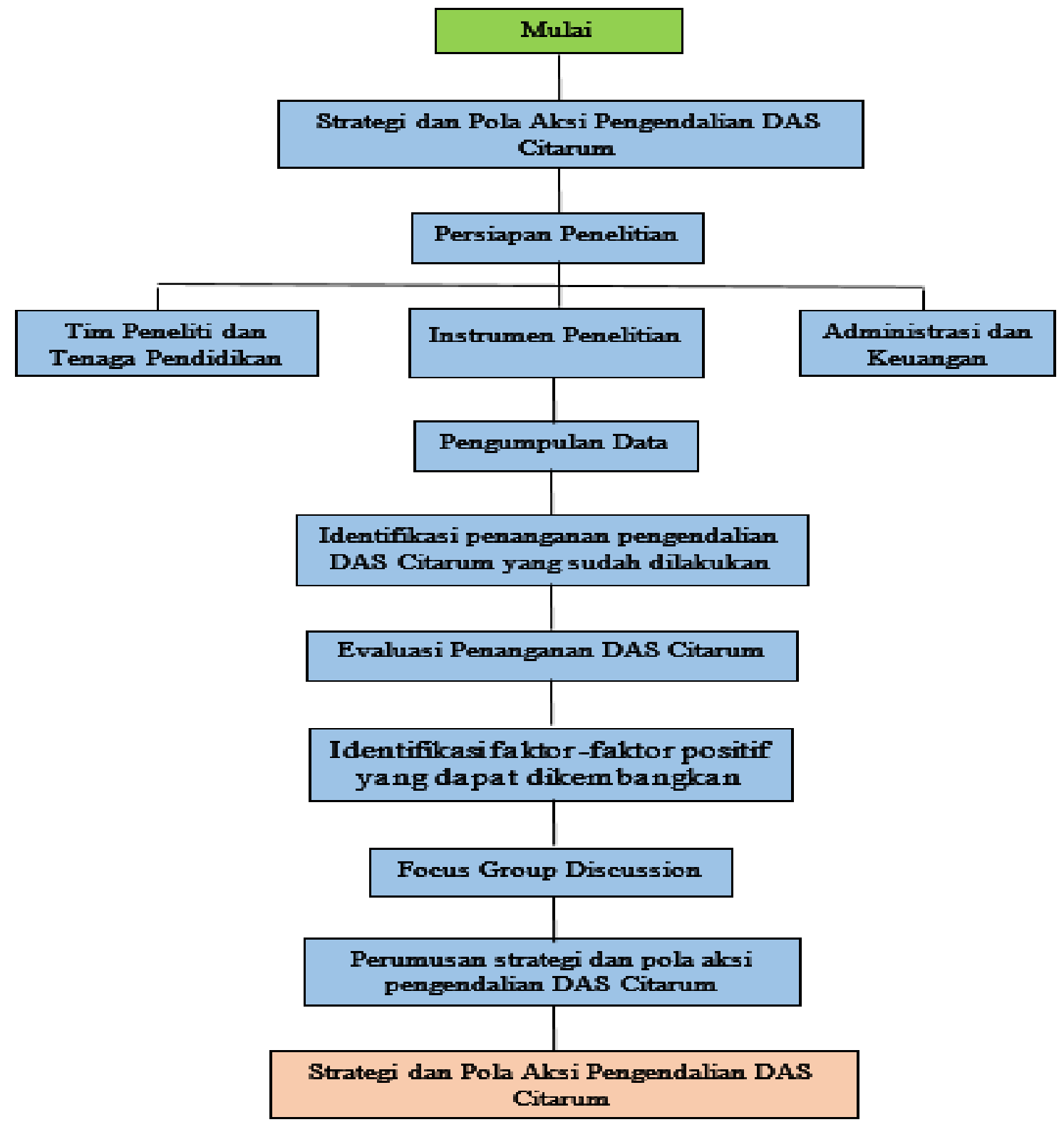

Gambar 2. Alur Proses Penelitian

\section{HASIL DAN PEMBAHASAN}

\section{a. Kondisi Sosial Ekonomi}

Wilayah penelitian mayoritas merupakan penduduk pendatang dengan persentase $53 \%$. Pendidikan yang pernah ditempuh oleh penduduk rata-rata yaitu sekolah menengan dasar (SD). Pekerjaan yang ditekuni penduduk di lokasi penelitian sebagian besar adalah buruh. Pekerjaan lainnya adalah pedagang, karyawan swasta, 
guru dan lainnya. S Status kepemilikan rumah di lokasi penelitian umumnya sudah milik sendiri dengan mayoritas merupakan kondisi bangunan rumah permanen. Sebaran ukuran rumah di lokasi kajian relative merata dari ukuran kecil, yaitu ukuran lebih kecil dari 50 $\mathrm{m} 2$ hingga lebih dari $100 \mathrm{~m}^{2}$ persentasenya berkisar antara 36 persen himgga 26 persen. Sebagian besar penduduk di wilayah kajian memanfaatkan sumur sebagai sumber air sehari-hari $(72 \%)$ Sebagain lainnya menggunakan air dari PDAM (18,7\%), dan sisanya menngunakan air dari sumur dan campuran antara dari sumur dan dari pabrik.

\section{b. Kondisi Sanitasi dan Sampah}

Dalam hasil penelitian mengenai kondisi sanitasi masyarakat di ketiga desa tersebut, dapat di ketahui bahwa belum semua masyarakat yang tinggal disana memiliki septic tank di rumahnya masing-masing. Dari 75 responden yang diwawancarai, 23 orang diantaranya belum memiliki septic tank sendiri di rumahnya. Masyarakat yang belum memiliki septic tank mengalirkan buangan dari WC maupun limbah cair rumah tangga ke selokan, baik secara terpisah maupun tidak. Selain itu, masih banyak masyarakat yang membuang limbah cair dari rumah tangganya tidak ke dalam septic tank yang ada di rumahnya, akan tetapi ke selokan yang ada di sekitarnya. Dari hasil wawancara yang diperoleh dapat diketahui bahwa dari 52 masyarakat yang memiliki septic tank, hanya 9 orang yang mengalirkan limbah cair rumah tangganya ke dalam septic tank, sisanya yakni sejumlah 42 orang mengalirkan limbah cair rumah tangganya ke selokan yang ada di sekitarnya. Selokan yang ada di wilayah tersebut mengalir ke sungai, baik sungai utama Citarum maupun anak sungainya. Sehingga dapat diketahui bahwa limbah rumah tangga dan buangan dari masyarakat sekitar sungai memiliki andil dalam pencemaran sungai. Berikut merupakan rincian tabel 1,2, dan 3 kondisi sanitasi, penanganan sampah dan kelembagaan.

Tabel 1. Kondisi Sanitasi

\begin{tabular}{|c|c|c|c|c|c|c|c|c|c|c|c|c|c|c|c|c|c|c|c|}
\hline \multicolumn{2}{|c|}{ Sumber air } & \multicolumn{2}{|c|}{$\begin{array}{c}\text { Kebersihan } \\
\text { jamban }\end{array}$} & \multicolumn{2}{|c|}{$\begin{array}{c}\text { Ketersediaan } \\
\text { Septic tank }\end{array}$} & \multicolumn{2}{|c|}{ Aliran WC } & \multicolumn{2}{|c|}{$\begin{array}{l}\text { Aliran limbah } \\
\text { cair }\end{array}$} & \multicolumn{2}{|c|}{$\begin{array}{c}\text { Ketersediaan } \\
\text { Saluran } \\
\text { drainase }\end{array}$} & \multicolumn{2}{|c|}{$\begin{array}{l}\text { Jarak ke } \\
\text { saluran } \\
\text { draingse }\end{array}$} & \multicolumn{2}{|c|}{$\begin{array}{c}\text { Aliran hujan } \\
\text { dan limbah }\end{array}$} & \multicolumn{2}{|c|}{$\begin{array}{c}\text { Instalasi } \\
\text { pengolahan } \\
\text { limbah }\end{array}$} & \multicolumn{2}{|c|}{$\begin{array}{c}\text { Septic } \\
\text { tank } \\
\text { komunal }\end{array}$} \\
\hline Sumur & 54 & Bersih & 44 & $\mathrm{Ada}$ & 52 & Septic tank & 51 & Septic tank & 9 & $\mathrm{Ada}$ & 72 & $<10 \mathrm{~m}$ & 59 & Terpisah & 19 & $\mathrm{Ada}$ & 2 & $\mathrm{Ada}$ & 2 \\
\hline PDAM & 14 & Cukup & 11 & $\begin{array}{l}\text { Tidak } \\
\text { ada }\end{array}$ & 23 & Selokan & 18 & Selokan & 58 & $\begin{array}{l}\text { Tidak } \\
\text { ada }\end{array}$ & 3 & $>10 \mathrm{~m}$ & 16 & $\begin{array}{l}\text { Tidak } \\
\text { terpigah }\end{array}$ & 56 & $\begin{array}{l}\text { Tidak } \\
\text { ada }\end{array}$ & 73 & $\begin{array}{l}\text { Tidak } \\
\text { ada }\end{array}$ & 73 \\
\hline $\begin{array}{l}\text { Sibel (sumur } \\
\text { bor } \\
\text { bersama) }\end{array}$ & 3 & Kurang & 13 & & & Sungai & 6 & Sungai & 8 & & & & & & & & & & \\
\hline $\begin{array}{l}\text { Sumur } \quad \& \\
\text { PDAM }\end{array}$ & 1 & $\begin{array}{l}\text { Tidak } \\
\text { bersihh }\end{array}$ & 4 & & & & & & & & & & & & & & & & \\
\hline $\begin{array}{l}\text { Bantuan } \\
\text { pabrik }\end{array}$ & 3 & & & & & & & & & & & & & & & & & & \\
\hline
\end{tabular}

Tabel 2. Penanganan Sampah

\begin{tabular}{|c|c|c|c|c|c|c|c|c|c|}
\hline $\begin{array}{c}\text { Jenis } \\
\text { sampah yg } \\
\text { dominan }\end{array}$ & Jumlah & $\begin{array}{l}\text { Sumber sampah } \\
\text { dominan }\end{array}$ & Jumlah & $\begin{array}{c}\text { Tempat } \\
\text { membuang } \\
\text { sampah }\end{array}$ & Jumlah & $\begin{array}{c}\text { Melakukan } \\
\text { pemilahan } \\
\text { sampah }\end{array}$ & Jumlah & $\begin{array}{c}\text { Cara } \\
\text { menangani } \\
\text { sampah } \\
\end{array}$ & Jumlah \\
\hline Plastik & 39 & Dapur & 18 & Tempat sampah & 63 & $\mathrm{Ya}$ & 11 & Dibuang & 50 \\
\hline Kertas & 2 & Pekerjaan & 5 & Lahan kosong & 4 & Tidak & 64 & Dibakar & 20 \\
\hline Kain & 2 & Rumah tangga & 37 & Dekat rumah & 7 & & & $\begin{array}{l}\text { Dibakar, } \\
\text { kemudian } \\
\text { dibuang }\end{array}$ & 5 \\
\hline Daun & 2 & Halaman rumah & 2 & Kebun & 1 & & & & \\
\hline Campur & 4 & Tidak tahu & 3 & & & & & & \\
\hline Tidak tahu & 26 & Warung \& dapur & 9 & & & & & & \\
\hline & & Davur \& toilet & 1 & & & & & & \\
\hline
\end{tabular}


Tabel 3. Kelembagaan

\begin{tabular}{|c|c|c|c|c|c|c|c|c|c|c|c|}
\hline $\begin{array}{l}\text { Petugas } \\
\text { sampah }\end{array}$ & Jumlah & $\begin{array}{c}\text { Sistem } \\
\text { penggajian }\end{array}$ & $\begin{array}{c}\text { Jumla } \\
\text { h }\end{array}$ & Kerja bakti & $\begin{array}{c}\text { Jumla } \\
\text { h }\end{array}$ & $\begin{array}{c}\text { Tanggapan thd } \\
\text { pengelolaan } \\
\text { gampah }\end{array}$ & $\begin{array}{c}\text { Jumla } \\
\text { h }\end{array}$ & $\begin{array}{l}\text { Penanganan } \\
\text { drainase limbah }\end{array}$ & Jumlah & $\begin{array}{l}\text { Penanganan } \\
\text { drainase hujan }\end{array}$ & Jumlah \\
\hline $\mathrm{Ada}$ & 64 & Iuran warga & 64 & $\mathrm{Ada}$ & 28 & Baik & 13 & $\mathrm{Ada}$ & 40 & Ads & 20 \\
\hline \multirow[t]{6}{*}{ Tidak ada } & 11 & & & Jarang & 10 & Cukup & 10 & Tidak ada & 60 & Tidak ada & 55 \\
\hline & & & & $\begin{array}{c}2 \text { minggu } \\
\text { gekali }\end{array}$ & 3 & Kurang baik & 34 & & & & \\
\hline & & & & $\begin{array}{c}\text { Sebulan } \\
\text { gekali }\end{array}$ & 7 & Buruk & 3 & & & & \\
\hline & & & & $\begin{array}{c}\text { Seminggu } \\
\text { gekali }\end{array}$ & 3 & Tidak tahu & 10 & & & & \\
\hline & & & & Insidental & 12 & & & & & & \\
\hline & & & & Tidak ada & 8 & & & & & & \\
\hline
\end{tabular}

\section{c. Dampak Banjir}

Berdasarkan hasil wawancara, dari 75 responden 39 orang diantaranya pernah mengalami banjir baik dengan frekuensi rendah, sedang maupun tinggi. Dari 39 orang yang mengalami banjir, 29 di antaranya menyatakan bahwa banjir memiliki dampak terhadap menurunnya perekonomian, terhambatnya aktivitas, serta munculnya penyakit (Tabel 4). Dari hasil wawancara diketahui bahwa dampak banjir terhadap perekonomian dirasakan oleh responden yang berprofesi sebagai pedagang, akibat dari banjir responden tidak bisa berjualan seperti biasanya. Masyarakat berpendapat bahwa peristiwa banjir dapat sangat menghambat aktivitas masyarakat yang seharusnya bekerja, sekolah, maupun aktivitas lainnya, karena frekuensi yang tinggi, waktu banjir yang lama, kedalaman banjir yang tinggi, dan cakupan wilayah yang luas (Tabel 4). Penyakit yang umumnya muncul dari banjir diantaranya DB, penyakit kulit, dan diare. Dalam hal ini, masyarakat terbantu dengan fasilitas kesehatan gratis yang diberikan pemerintah bagi warga yang terkena banjir. Berdasarkan analisis ditemukan pernyataan masyarakat akibat dampak banjir (tabel 5).

Tabel 4. Kejadian Banjir di Lokasi Penelitian

\begin{tabular}{|c|c|c|c|c|c|c|c|}
\hline Frekuensi & Jml & Kedalaman & Jml & Luas & Jml & Lama & Jumlah \\
\hline 5 tahun sekali & 3 & $>1 \mathrm{~m}$ & 8 & Satu desa & 7 & $\begin{array}{c}\text { Satu } \\
\text { bulan }\end{array}$ & 6 \\
\hline 3 tahun sekali & 1 & $1 \mathrm{~m}$ & 13 & Satu kampung & 11 & $\begin{array}{c}\text { Dua } \\
\text { minggu }\end{array}$ & 7 \\
\hline Jarang & 4 & $>1 \mathrm{~m}$ & 10 & Satu RT & 2 & $\begin{array}{c}\text { Satu } \\
\text { minggu }\end{array}$ & 7 \\
\hline 3x getahun & 4 & & & Satu RW & 1 & Satu hari & 2 \\
\hline lx setahun & 27 & & & & & & \\
\hline Tidak pernah & 36 & & & & & & \\
\hline
\end{tabular}

Tabel 5. Dampak Banjir

\begin{tabular}{|l|c|}
\hline \multicolumn{1}{|c|}{ Pernyataan } & Jumlah \\
\hline $\begin{array}{l}\text { Menurunnya perekonomian responden akibat } \\
\text { banjir }\end{array}$ & 5 \\
\hline Terhambatnya aktivitas responden akibat banjir & 17 \\
\hline Munculnya berbagai penyakit akibat banjir & 17 \\
\hline
\end{tabular}




\section{d. Strategi Penanganan Pencemaran Citarum}

Secara empiris, beberapa dampak yang ditimbulkan akibat kualitas air sungai yang jelek, antara lain: (1) tuntutan perlakuan dan teknologi pengolahan air bersih yang bersumber dari air baku sungai menjadi lebih berat dan mahal; (2) pencemaran udara, bau; (3) pencemaran airtanah, sumur penduduk; (4) gannguan kesehatan lingkungan yang berimbas pada ganguan kesehatan penduduk sekitar, penyakit pencernaan dan saluran pernafasan; (5) tingkat kenyamanan penduduk sekitar sunhai menjadi sangat rendah; (6) intensitas pemeliharaan waduk dan biaya operasi dan pemeliharaan sungai dan waduk menjadi sangat mahal; (7) konflik horizontal; dan (8) nama baik Indonesaia di mana dunia.

Beberapa identifikasi dampak di atas, menunjukkan bahwa sungai yang semestinya berfungsi sebagai penyangga dan pendukung kehidupan "diubah" menjadi beban hidup dan kehidupan. Sungai yang semestinya menjadi lambang dari kemakmuran, kesejateraan, dan kedamaian "berubah" menjadi sumber masalah dan petaka.

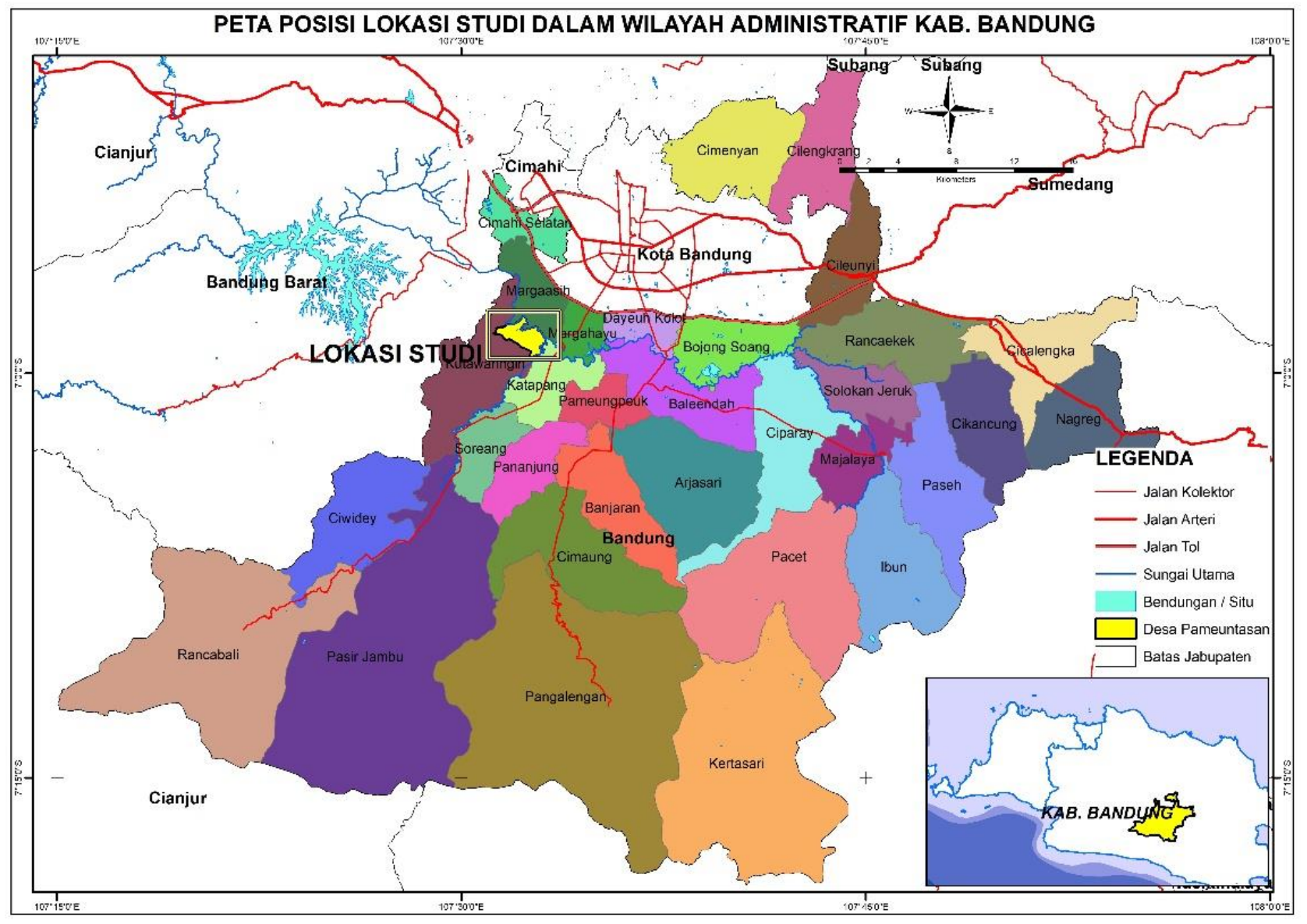

Gambar 2. Desa Pameuntasan

Desa Pameuntasan, Kecamatan Kutawaringin Kabupaten Bandung, merupakan salah satu desa yang wilayahnya langsung berbatasan dengan sungai Citarum (Gambar 2). Secara empirik nampak bahwa desa ini belum mempunyai system saluran drainase dan pengolahan limbah dan sampah yang terintegrasi dan terkoneksi dengan baik; dan sanitasi lingkungan masih sangat perlu diperbaiki. Selain itu, isu-isu yang berkembang di desa ini antara lain: rendahnya kesadaran dan pengetahauan masyarakat terhadap perlunya sanitasi-lingkungan; belum adanya penanganan dan pengelolaaan limbah dan sampah yang baik, tuntas dan aman; belum sinerginya berbagai program dan kegiatan pemerintah berbasis lingkungan di tingkat desa; mendesaknya penanganan system drainase dan perkuatan tebing sungai; masih terbatasnya intensitas pengangkutan sampah; potensi pencearan airtanah dan udara; potensi konflik horizontal; keterbatasan respons stake 
holder terhadap keluhan dan kebutuhan masyarakat; dan belum terbangunnya Lembaga yang bekerja untuk membangun kepedulian Masyarakat tentang pentingnya Sanitasi-Lingkungan yang baik.

Dalam konteks lokasi Sungai Citarum, strategi penanhanan pencemaran ditujukan untuk memperbaiki, menjaga dan kualitas lingkungan dan kesehatan masyarakat sekitar Sungai Citarum, namun juga ditujukan untuk memperbaiki dan memelihara kualitas air Sungai Citarum. Megingat panjangnya sungai citarum, luasanya DAS yang mempemgaruhi air sungai Citarum, bannyak dan variatifnya desa yang terdapat di Citarum sudah barang tentu pekerjaan memperbaiki kualitas air sungai citarum bukan pekerjaan mudah dan instan. Namun demikian, kegiatan strategi penanganan pencemaran ini perlu dilakukan dalam satu tempat/lokasi yanh terbatas sebagai pilot kajian. Hasilmya diharapkan menjadi row model tentang bagaimana melakukan penataan lingkungan/sanitasi di tingkat desa/kampung dengan basis kemitraan. Hingga, jika kegiatan sejenis dikembangkan ke wilayah yang lebih luas akan memberikan dampak positif bagi perbaikan kualitas air sungau Citarum.

Berdasarkan fakta di atas, perlu dilakukan Rancang Bangun Penataan Sanitasi berbasis Kemitraan. Tujuannya adalah:

1. membangunan kemitraan antara Perguruan Tinggi, pihak Desa, Pemerintah Daerah, dan stake holder lain untuk secara bersama-sama berusaha memperbaiki air dan sungai Citarum melalui Pembentukan dan pengembangan Desa Peduli Sanitasi;

2. membantu memfasilitasi meningkatkan kesadaran dan pengetahuan masyarakat tentang pentingnya sanitasi lingkungan yang baik dan aman;

3. memasiltasi pembentukan/pengembangan kelembagaan "peduli Sanitasi" di tingkat desa;

4. membantu dalam Pencanangan Desa Pameuntasan sebagai Desa Peduli Sanitasi yang nagai

5. membantu/memfasilitasi penyusunan perencanaan/perancangan system drainase yang terkoneksi dengan baik dan aman;

6. membantu/memfasilitasi penyusunan perencanaan/perancangan system penanganan dan pengolahan limbah dan sampah;

7. membantu/memfasilitasi penyusunan rencana pelaksanaan program perbaikan lingkungan secara sinergi dan terintegrasi;

8. membantu dan memediasi dalam implementasi kemitraan untuk pelaksanaan pembangunan hasil perencanaan/perancangan, baik pengelolaan system drainase, limbah, sampah, maupun degradasi sanitasilingkungan lainnya;

Target atau sasaran akhirnya adalah:

1. Terbentuknya lokasi Pilot Kajian sebagai row model Desa Peduli Sanitasi yang bercirikan: mempunyai kelembagaan sanitasi-lingkungan; sanitasilingkugannya baik, aman dan sehat; dan mandiri dalam pengelolaan sanitasi.

2. Terbentuknya kemitraan yang kokoh dan mampu bekerja sinergi untuk membangun dan mengembangkan row model penanganan pencemaran Sungai Citarum.

\section{SIMPULAN}

Berdasarkan hasil pengamatan lapangan wawancara dengan masyarakat, dapat disimpulkan beberapa hasil berikut:

1. Sebagain besar limbah dibuang langsunh ke sungai melalui saluran-saluran drainase tanpa pengolahan terlebih dahulu. Saluran drainase ini, sebagai belum terkoneksi dengan baik, hinggag terdapat genangan di beberapa saluran dan lahan. Kondisi ini menimbulkan bau yang kurang sedap dan lingkungan yang tidak sehat.

2. Secara rill permasalahan prioritas di daerah kajian adalah:

a) tidak adanya lembaga/kelembagaan khusus untuk menangani masalah lingkungan

b) tidak adanya system drainasse yang terkoneksi dengan baik;

c) tidak ada adanya penanganan dan pengolahan limbah dan sampah yang baik dan tuntas;

d) tidak adanya sinerginisitas antar program berbasis lingkungan di tingkat desa;

e) belum terbentuk kegiatan berbasis kemitraan pada tingkat satuan adminitratif terkecil/desa, yang dapat 
dijadikan row model (kelembagaan dan fisik) penanganan dan pengolahan limbah, sampah dan drainase secara terintegrasi, sinergi dan berkelanjutan.

3. Sebagian besar masyarakat mengerti dan paham tentang perlunya lingkungan yang sehat, terbukti dengan beberapa kegiatan yang sudah dilaksanakan walaupun semampunya masyrakat dan belum tuntas. Permasalahan dana dan kemampuan rekayasa lingkungan yang belum memamdai sebagai salah satu penyebabnya. Oleh karenan itu diperkukan perancangan kegiatan berbasis kemitraan antar stake holder dan masyarakat, dengana tujuan:

a) membangunan kemitraan antara Perguruan Tinggi, pihak Desa, Pemerintah Daerah, dan stake holder lain untuk secara bersama-sama berusaha memperbaiki air dan sungai Citarum melalui Pembentukan dan pengembangan Desa Peduli Sanitasi;

b) membantu memfasilitasi meningkatkan kesadaran dan pengetahuan masyarakat tentang pentingnya sanitasi lingkungan yang baik dan aman;

c) memfasiltasi

pembentukan/pengembangan

kelembagaan "peduli Sanitasi" di tingkat desa;

d) membantu dalam Pencanangan Desa Pameuntasan sebagai Desa Peduli Sanitasi yang berkelanjutan

e) membantu/memfasilitasi penyusunan perencanaan/perancangan system drainase yang terkoneksi dengan baik dan aman;

f) membantu/memfasilitasi penyusunan perencanaan/perancangan system penanganan dan pengolahan limbah dan sampah;

g) membantu/memfasilitasi penyusunan rencana pelaksanaan program perbaikan lingkungan secara sinergi dan terintegrasi;

h) membantu dan memediasi dalam implementasi kemitraan untuk pelaksanaan pembangunan hasil perencanaan/perancangan, baik pengelolaan system drainase, limbah, sampaj, maupun degradasi sanitasilingkungan lainnya;

\section{REKOMENDASI}

Berdasarkan kesimpulan di atas, maka direkomendasikan hal-hal sebagai berikut:

1. Melalukan pemetaan terhadap masalah pencemaran terutama yang bersumber dari ruman tangga dan insdutri. Pemetaan tidak bersifat pemetaan fisik tetapi juga pemetaan terhadap pola pikir, mentalitas dan prilaku masyarakat. Kegiatan ini sdh dimulai namun masih belum tuntas dan perlu dilanjutkan dan diperdalam

2. Melakukan pilot tindakan pengendalian pencemaran untuk suatu lokasi tertentu yang berorientasi pada:

a) Terbentuknya lokasi Pilot Kajian sebagai row model Desa Peduli Sanitasi yang bercirikan: mempunyai kelembagaan sanitasi-lingkungan; sanitasi-lingkugannya baik, aman dan sehat; dan mandiri dalam pengelolaan sanitasi.

b) Terbentuknya kemitraan yang kokoh dan mampu bekerja sinergi untuk membangun dan mengembangkan row model penanganan pencemaran Sungai Citarum.

\section{DAFTAR PUSTAKA}

Agustiningsih, D. Sasongko, S, B. \& Sudarno. 2012. Analisis Kualitas Air dan Strategi Pengendalian Pencemaran Air Sungai Blukar Kabupaten Kendal. Jurnal Presipitasi, 9. 64-71. ISSN 1907-87X.

Anggiani, P. Sumarni, Ruja, L.N. \& Bachri, S. 2018. River Management: The Importance of The Roles of The Public Sector and Community in River Preservation in Banjarmasin (A Case Study of The Kuin River, Banjarmasin, South Kalimantan - Indonesia). Sustainability Citien and Society, 43, 1120.

https://doi.org/10.1016/j.scs.2018.08.00 4

Dawud, M. Namara, I. Chayati, N. \& Muhammad, F. 2016. Analisis Sistem Pengendalian Pencemaran Air Sungai 
Cisadane Kota Tanggerang Berbasis Masyarakat. Seminar Nasional Sains dan Teknologi, Fakultas Tehnik Universitas Muhammadiyah Jakarta. e-ISSN: 24608416.

Muin, S., Muin, S. F., Boer, R., \& Suharnoto, Y. 2015. Pemodelan Banjir dan Analisis Kerugian Akibat Bencana Banjir di DAS Citarum Hulu. Jurnal Tanah Dan Iklim, $39(2)$, $75-84$. https://doi.org/10.2017/jti.v39i2.6224

Mulyana Arif Jaya, N., \& Risdiyanto, I. 2013. Rencana Tindak Pengelolaan DAS Citarum. https://doi.org/10.13140/RG.2.1.1880.4 727
Rohmat, D., Setiawan, I., \& Affriani, A.R., 2018. Zonasi Karakteristik Pencemaran untuk Penyusunan Strategi dan Pola Aksi Penanganan Sungai Menuju Citarum Harum (Pemetaan dengan Citra Tegak Resolusi Tinggi). Laporan Penelitian. LPPM UPI. Bandung

Tsaboula, A. Menexes, G. Papadakis, E. Vryzas, Z. Kotopoulou, A. Kintzikoglou, K. \& Papadopoulou-Mourkidou, E. 2019. Assessment and Management of Presticide Pollution at a River Basin Level Part II: Optimization of Pesticide Monitoring Networks on Surface Aquatic Ecosystems by Data Analysis Methods. Science of the Total Envinronment, 653, 1612-1622. https://doi.org/10.1016/j.scitotenv.2018. 10.270 . 